ANUVA Volume 1 (2): 119-131, 2017

Copyright (C2017, ISSN: 2598-3040 online

Available Online at: http://ejournal.undip.ac.id/index.php/anuva

\title{
Penerapan Literasi Informasi Berdasarkan Kemampuan Berbahasa Inggris : Studi Kasus Mahasiswa Prodi S1 IImu Perpustakaan FIB Undip Angkatan 2013
}

\author{
Sri Ati Suwanto ${ }^{1 *}$, Jumino ${ }^{2}$ \\ ${ }^{1}$ Program Studi Ilmu Perpustakaan Fakultas Ilmu Budaya, Universitas Diponegoro, \\ Jl. Prof. Soedarto, SH, Kampus Undip Tembalang, Semarang, Indonesia. \\ ${ }^{2}$ Program Studi Sastra Inggris, Fakultas Ilmu Budaya, Universitas Diponegoro, \\ Jl. Prof. Soedarto, SH, Kampus Undip Tembalang, Semarang, Indonesia. \\ ${ }^{*}$ Korespondensi : tikasuwanto@gmail.com
}

\begin{abstract}
The purpose of this study is to find out how the application of information literacy based on the students' English ability of S1 Library Science Study Program Faculty of Humanities Diponegoro University of Semarang, year 2013. The research method used is descriptive qualitative with case study type. The subject of this research is the students of S1 Library Science Study Program, year 2013, and the object of English proficiency and its application for information literacy. Data collection was done by interview and document study. The informants were chosen by purposive sampling, that is, the students of S1 Library Science Study Program Faculty of Humanities Diponegoro University of Semarang, year 2013 who have got information literacy subject amount of 15 students. The result of the research shows that the students of year 2013 have used English to be literate. They understand their needs, then seek information either from international journals, via internet, or from the library. The use of their information is clear, that is, to support in writing thesis. They can overcome their lack of English language skills.
\end{abstract}

Keywords: information literacy; english ability; s1 library science study program diponegoro university

\begin{abstract}
Abstrak
Tujuan penelitian ini adalah untuk mengetahui bagaimana penerapan literasi informasi berdasarkan kemampuan berbahasa Inggris oleh mahasiswa Prodi S1 Ilmu Perpustakaan Fakultas Ilmu Budaya Universitas Diponegoro Semarang angkatan 2013. Metode penelitian yang digunakan adalah kualitatif deskriptif dengan jenis studi kasus. Subyek penelitiannya adalah mahasiswa prodi S1 Ilmu Perpustakaan angkatan tahun 2013, dan objeknya kemampuan berbahasa Inggris dan penerapan nya untuk literasi informasi. Pengumpulan data dilakukan dengan wawancara dan studi dokumen. Informan dipilih dengan cara purposive sampling, yaitu mahasiwa prodi Ilmu Perpustakaan angkatan tahun 2013 yang sudah mendapatkan mata kuliah literasi informasi sebanyak 10 orang. Hasil peneltian menunjukkan bahwa mahasiswa angkatan 2013 telah menggunakan bahasa Inggris untuk menjadi literat. Mereka memahami kebutuhan mereka, kemudian mencari informasi dari jurnal-jurnal internasional baik melalui internet, maupun dari perpustakaan. Penggunaan informasi mereka sudah jelas yaitu untuk mendukung penulisan skripsi. Mereka dapat mengatasi permasalahan kemampuan bahasa Inggris mereka yang kekurang.
\end{abstract}

Kata Kunci: literasi informasi; kemampuan berbahasa inggris; prodi s1 ilmu perpustakaan universita diponegoro

\section{Pendahuluan.}

Becoming a superior research university in 2020 adalah jargon yang digadang-gadang oleh Universitas Diponegoro. Jargon tersebut menjadi visi Universitas Diponegoro yang ditularkan 
kepada seluruh fakultas yang ada di Universitas Diponegoro. Salah satu fakultas yang ada di Universitas Diponegoro adalah Fakultas Ilmu Budaya. Fakultas Ilmu Budaya pun juga memiliki visi yang senada dengan visi Universitas Diponegoro. Adapun visi Fakultas Ilmu Budaya adalah menjadi fakultas riset yang unggul di Asia Tenggara pada tahun 2025 dalam bidang kebudayaan yang meliputi sastra, bahasa, sejarah, antropologi, perpustakaan, filsafat, dan kearsipan.

Perguruan tinggi sebagai institusi pendidikan tinggi berkewajiban memberikan pendidikan dan pengarahan kepada mahasiswanya agar mampu melakukan kegaiatan penelitian dengan baik dan bertanggung jawab. Kegiatan penelitian yang baik artinya mahasiswa mampu menelusur sumber referensi yang bereputasi, sedangkan kegaiatan penelitian yang bertanggung jawab yaitu mahasiswa mengetahui etika dan hukum akademis seputar penggunaan informasi. Oleh karena hal tersebut penting bagi perguruan tinggi memberikan bekal kemampuan literasi informasi dalam wadah instruksi literasi informasi yang berkelanjutan dan terintegrasi (Paterson and Gamtso 2016; Walker and Pearce 2014; Boger et al. 2016). Melalui instruksi literasi informasi tersebut maka akan menumbuhkan kepercayaan diri mahasiswa terhadap kemampuan literasi informasinya. perihal tersebut telah banyak diteliti oleh penelitian sebelumnya, dinyatakan bahwasanya terdapat hubungan positif antara kepercayaan diri kemampuan literasi seorang individu terhadap kemampuan literasi informasi (Pinto and Fernandez Pascual 2016; Pinto, Fernandez-Pascual, and Puertas 2016; Shao and Purpur 2016).

Segenap kegiatan belajar mengajar yang dilakukan oleh mahasiswa semenjak semester satu telah dilatih untuk melakukan penelitian. Pelatihan tersebut terangkum dalam tugas-tugas yang diberikan oleh dosen pengajar. Dalam tugas yang diberikan, mahasiswa dilibatkan untuk mengobservasi sebuah fenomena alam atau sosial, kemudian mengumpulkan data dari hasil observasi tersebut, dan membuat laporan dari data yang didapat. Mahasiswa dilatih dan dibimbing untuk mempelajari dan mengembangkan kemampuan berbagai bidang disiplin ilmu yang tercakup dalam kurikulum pembelajaran. Bahasa Inggris merupakan bahasa internasional yang salah satunya berfungsi sebagai bahasa ilmu pengetahuan dan teknologi. Banyak referensi pembelajaran, baik berupa buku, artikel jurnal, maupun dokumen ditulis dalam bahana Inggris. Hal ini menuntut mahasiswa, khususnya mahasiswa Prodi Ilmu Perpustakaan Undiversitas Diponegoro untuk bisa menguasai bahasa Inggris dalam rangka mendapatkan informasi untuk penyerapan dan pengembangan pengetahuan yang mereka pelajari.

Untuk dapat melakukan penelitian dengan baik, seorang mahasiswa harus memiliki ketrampilan dalam menerapkan literasi informasi. Terlebih lagi di era informasi seperti saat ini, informasi sangat melimpah dan mudah untuk didapatkan. Namun jika mahasiswa yang sedang melatih dirinya untuk menjadi literat tidak kritis, mereka dapat terjebak dalam informasi yang tidak relevan bahkan tidak valid. Untuk dapat memiliki ketrampilan yang harus dimiliki oleh mahasiswa dalam belajar, harus memiliki kemampuan literasi informasi. Selanjutnya kemampuan literasi 
informasi berdasarkan kemampuam berbahasa Inggris mahasiswa mutlak perlu diterapkan. Bagaimana mungkin mahasiswa bisa memahami ilmu pengetahuan yang referensinya banyak ditulis dalam bahasa Inggris kalau mereka tidak memiliki kemampuan untuk itu. Oleh karena itu mucul pertanyaan penelitian bagaimana penerapan literasi informasi berdasarkan kemampuan berbahasa Inggris khususnya oleh mahasiswa Prodi S1 Ilmu Perpustakaan Fakultas Ilmu Budaya Universitas Diponegoro Semarang Angkatan 2013.

Tujuan penelitian ini adalah untuk mengetahui bagaimana penerapan literasi informasi informasi berdasarkan kemampuan berbahasa Inggris oleh mahasiswa Prodi S1 Ilmu Perpustakaan Fakultas Ilmu Budaya Universitas Diponegoro Semarang angkatan 2013. Penelitian ini penting dilakukan karena dengan diketahuinya kemampuan penggunaan Bahasa Inggris dalam Literasi Informasi dapat digunakan untuk memberikan solusi perubahan program pengajaran Bahasa Inggris dan Literasi informasi dalam kurikulum tahun 2017 - 2021. Metode penelitian yang digunakan adalah kualitatif deskriptif dengan jenis studi kasus. Subyek penelitiannya adalah mahasiswa prodi S1 Ilmu Perpustakaan angkatan tahun 2013, dan objeknya kemampuan berbahasa Inggris dan penerapan nya untuk literasi informasi. Pengumpulan data dilakukan dengan wawancara dan dokumen yang berasal dari skripsi mahasiswa angkatan 2013. Informan dipilih dengan cara purposive sampling, yaitu mahasiwa prodi Ilmu Perpustakaan angkatan tahun 2013 yang sudah mendapatkan mata kuliah literasi informasi sebanyak 15 orang.

Pada tahun 2000 Association of College and Research Libraries (ACRL) memberikan deskripsi karakteristik mengenai seseorang yang memiliki kemampuan literasi informasi sebagai berikut :

1) Menentukan informasi yang dibutuhkan

2) Mengakses kebutuhan informasinya secara efektif dan efisien

3) Mengevaluasi informasi dan sumber-sumber yang didapatkannya secara kritis.

4) Menggabungkan Informasi yang dipilihnya menjadi sebuah landasan pengetahuan

5) Menggunakan informasi secara efektif untuk mencapai tujuan tertentu

6) Mengetahui isu-isu ekonomi, hukum, dan sosial seputar penggunaan informasi, serta menggunakan informasi secara etis dan legal.

Boekhorst (2003) mendefinisikan Literasi Informasi melalui 3 konsep, yaitu: ICT concept: mengacu pada kompetensi dalam menggunakan ICT untuk menemukan dan menyebarluaskan informasi. Information Resource conpept: kompetensi menemukan dan menggunakan informasi secara mandiri maupun melalui bantuan perantara. Information Process concept: kompetensi mengenali kebutuhan informasi, menemukan, mengevaluasi, menggunakan, dan menyebarluaskan informasi untuk memperoleh dan menambah pengetahuan baru (tercakup konsep ICT dan IR). Kemudian UNESCO (2007) 
mendeskripsikan bahwa Literasi informasi mengarahkan pengetahuan akan kesadaran dan kebutuhan informasi seseorang, dan kemampuan untuk mengidentifikasi, menemukan, mengevaluasi, mengorganisasi dan secara efektif menciptakan, menggunakan, mengomunikasikan informasi untuk mencari solusi atas masalah yang dihadapi. Sementara itu menurut Armstrong (2015) adalah "Information literacy involves the knowledge and use of skills or competencies that together make for effective and appropriate use of information" yang pengertiannya adalah kemampuan yang berkaitan dengan pengetahuan dan penggunaan kemampuan atau kompetensinya bersama-sama yang membuat penggunaan informasi secara tepat dan efektif. Dalam penelitian ini literasi informasi yang digunakan sesuai dengan teori dari Armstrong (2015) tersebut di atas, karena terkait dengan kemampuan penggunaan informasi.

Menurut Bruce, dalam Pendit (2013), pemikiran tentang literasi informasi di kalangan pustakawan muncul bersamaan dengan kehadiran konsep "masyarakat informasi" (information society). Literasi informasi baru muncul dalam publikasi final report American Library Association tahun 1989, dan sejak itulah konsep literasi informasi mulai digunakan secara meluas. Menurut Pendit (2013) yang mengulas tulisan Bruce (1997), menyatakan bahwa dari tabel yang dibuat Bruce, ada dua hal yang disepakati dari sisi konsep dan sisi praktik, yaitu bahwa literasi informasi merupakan persoalan penggunaan teknologi informasi, dan bahwa literasi informasi merupakan sebuah proses penerapan keterampilan. Kemudian Donaldson (2004) memberikan batasan ketrampilan-ketrampilan yang harus dimiliki oleh mahasiswa dalam melakukan penelitian di era informasi kini, antara lain:

1. Mengetahui topik apa yang akan dicari, dengan Fokus pada topik (persempit topik/perluas ruang lingkup)

2. Memahami signifikansi terminologi dan tentukan tajuk subjek yang benar

3. Menganekaragamkan sumber (gunakan buku, majalah, situs internet,dll)

4. Gunakan strategi Boelean (AND,OR,NOT) pada penelusuran komputer

5. Evaluasi secara kritis materi yang ditemubalik;

6. Sitir semua sumber.

Untuk dapat memahami terminologi dari sumber sumber informasi yang kebanyakan bisa di dapat secara lengkap dari website, mahasiswa harus dapat mengerti bahasa Inggris dengan baik. Dari beberapa penulis (Yona, May, 2017; Zaky, 2017; Setyawati, 2016), menyebutkan bahwa dalam bahasa Inggris terdapat empat jenis skill yang diperlukan mahasiswa, yaitu listening, speaking, reading dan writing. Ke empat skill tersebut penting untuk dikuasai ketika ingin belajar dan menggunakan bahasa Inggris. Dalam penelitian ini kemampuan menggunakan bahasa Inggris karena terkait pemahaman membaca artikel maka kemampuan berbahasa Inggris yang digunakan 
dalam penelitian ini hanya reading,yang dikaitkan dengan comprension (Reading comprension) atau pemahaman membaca.

\section{Metode Penelitian}

Metode penelitian yang digunakan dalam penelitian ini adalah pendekatan kualitatif. Adapun jenis penelitian yang digunakan yaitu studi kasus. Subjek dalam penelitian ini yaitu mahasiswa Prodi S1 Ilmu Perpustakaan Fakultas Ilmu Budaya Universitas Diponegoro Semarang angkatan 2013, dan objek nya yaitu penerapan literasi informasi berdasarkan kemampuan berbahasa Inggris oleh mahasiswa Prodi S1 Ilmu Perpustakaan Fakultas FIB UNDIP angkatan tahun 2013.

Pertanyaan penelitian untuk Literasi informasi menggunakan teori Donaldson (2004), sedangkan pertanyaan penelitian untuk Kemampuan bahasa Inggris ada 4 yaitu, listening, speaking, reading dan writing. Informan dalam penelitian ini dipilih dengan cara purposive sampling, sesuai dengan tujuan penelitian ini, yaitu mahasiswaangkatan 2013 yang telah dan sedang melakukan penelitian untuk skripsinya. Jumlah informan sejumlah 10 orang

\section{Hasil penelitian dan Pembahasan.}

Penelitian ini dimulai dengan wawancara kepada informan sebanyak 10 orang mahasiswa S1 Ilmu Perpustakaan angkatan tahun 2013 tentang literasi informasi yang terdiri dari pertanyaanpertanyaan penelitian : 1) apakah informan mengetahui informasi yang dibutuhkannya 2) Memahami signifikansi terminologi dan tentukan tajuk subjek yang benar; 3) Menganekaragamkan sumber (gunakan buku, majalah, situs internet,dll); 4) Gunakan strategi Boolean (AND,OR,NOT) pada penelusuran komputer; 5) Evaluasi secara kritis materi yang ditemubalik; 6) Sitir semua sumber.

Untuk dapat memahami terminologi dari sumber sumber informasi yang kebanyakan bisa di dapat secara lengkap dari website, mahasiswa harus dapat mengerti bahasa Inggris dengan baik. Oleh karena itu diperlukan pertanyaan penelitian tentang kemampuan menggunakan Bahasa Inggris yaitu: listening, speaking, reading dan writing.

Dari hasil wawancara terhadap pertanyaan penelitian tentang literasi informasi atas pertanyaan penelitian tentang pengetahuan informasi yang dibutuhkan, 7 informan menjawab bahwa mereka mengetahui sumber informasi yang dibutuhkan, karena sudah memilih topik penelitian, dan yang 3 orang mengatakan bahwa mereka mengetahui yang mereka butuhkan karena topik penelitian sudah mereka tentukan sejak mengikuti kuliah Seminar di semester 7. Dengan demikian semua informan telah mengehui informasi yang telah mereka butuhkan terlebih dulu.

Ad.1) Tentang pemahaman tentang signifikansi terminologi ditanyakan apakah cara mencari informasi, satu orang menyaranakan cara pencarian melalui nama peneliti; lima orang 
menggunakan kata kunci ditambah cara pencarian menggunakan boolean Logic dan kata kunci nama penulis; satu orang menyarankan memanfaatkan situs pengunduh khusus (scihub.cc dan libgen.io/scimag. Dengan demikian sebagian besar informan menggunakan kata kunci, dan atas jawaban pertanyaan lebih lanjut mengapa menggunakannya, mereka menjawab karena hasilnya lebih tepat, jika tajuk subjeknya tepat. Jadi sebagian besar informan memahami pentingnya terminologi informasi atau kata kunci yang dicari.. Kemudian atas pertanyaan pentingnya memahami terminologi dari topik yang dicari, hampir semua informan (8 ) menyatakan bahwa terminologi sangat diperlukan karena agar ssesuai dengan apa yang mereka cari, dan 2 lainnya menyatakan terminologi di awal pencarian masih agak bingung, sehingga kurang sesuai dengan hasil yang dicari; tetapi setelah konsultasi dengan dosen pembimbing menjadi jelas. Dengan demikian semua informan menyatakan bahwa terminologi sangat penting untuk mendapatkan hasil sesuai dengan kebutuhan mereka.

Ad.2) Tentang cara mencari informasi, diperoleh jawaban bahwa tujuh dari sepuluh informan mencari informasi melalui internet, baik melalui sosial media, browsing melalui web, dan yang tiga lainnya di samping itu juga tanya ke teman-temannya dan mencari informasi ke perpustakaan. Dengan demikian mereka semua mencari informasi melalui internet dan sebagian menggunakan buku cetak. Hal ini dapat dipahami karena mereka semua termasuk generasi Digital Native, yaitu generasi yang telah tertempa penggunaan komputer sejak usia masih dini, sehingga mempengaruhi cara berpikir mereka untuk memperoleh dan memprosesinformasi. Generasi ini berbeda dengan generasi sebelumnya yaitu Digital immigrant (Pendatang Digital). ( Pendit, 2013).

Ad.3) Selanjutnya pertanyaan tentang sumber apa saja yang digunakan dalam mencari informasi yang dibutuhkan, diperoleh jawaban bahwa 6 dari 10 informan menggunakan jurnal, baik tercetak maupun internet, dan yang lain menggunakan buku cetak. Kemudian pertanyaan tentang sumber yang dipergunakan diperdalam dengan pertanyaan tentang cara mencari informasi, diperoleh jawaban tujuh dari sepuluh informan mencari informasi melalui internet, baik melalui sosial media, browsing melalui web, dan yang tiga di samping itu juga mencari ke perpustakaan. Dengan kebanyakan informan mencari informasi melalui internet, maka pertanyaan dipertajam dengan mesin pencari. apa yang digunakan, diperoleh jawaban semua informan mencari informasi melalui mesin pencari Google chrome. Dengan demikian lebih dari separo informan telah menganeka-ragamkan sumber informasi dan juga saranasarana pencarian informasi.

Ad.4) Jawaban informan untuk indikator literasi informasi ke 4 tentang penggunaan strategi Boolean, lima orang mengguanakan kata kunci ditambah cara pencarian menggunakan 
boolean Logic dan kata kunci nama penulis; satu orang menyarankan memanfaatkan situs pengunduh khusus (sci-hub.cc dan libgen.io/scimag. Dengan demikian sebagian besar informan sudah menggunakan Boolean logic. Hal ini dapat dimaklumi karena mereka semua sudah mendapat kuliah Temu balik informasi yang mengajarkan cara-cara mencari informasi dengan cepat dan tepat.

Ad.5) Jawaban tentang cara mengevaluasi materi yang ditemu balik. Dari sepuluh informan, enam orang informan melakukannya dengan melihat kandungan isi informasinya apakah sesuai dengan yang dibutuhkan atau tidak, satu informan melihat kabaharuan informasi tersebut, dan tiga orang informan dengan melihat relevansi isi informasinya. Dengan demikian sebagian besar informan sudah melakukan evaluasi isi informasi yan digunakannya.

Ad.6. Kemudian pertanyaan dikembangkan apakah mereka sudah menyitir semua sumber, diperoleh jawaban bahwa hampir semua informan (7 orang) menggunakan sumber informasi yang beragam, ada yang mencari dari perpustakaan, kemudian kalau tidak ketemu dari internet, ada yang langsung dari internet. Terkait pencarian melalui internet, tujuh informan menyatakan mereka menggunakan portal jurnal internasional dan hanya dua orang yang mencari langsung dari Google, dan satu orang menggunakan blog dosen. Jadi informan sudah menyitir informasi dari berbagai sumber, baik dari perpustkaan maupun dari internet, termasuk dari portal e-Journal dan blog dosen.

Untuk dapat memahami terminologi dari sumber sumber informasi yang kebanyakan bisa di dapat secara lengkap dari website, mahasiswa harus dapat mengerti bahasa Inggris dengan baik. Kemampuan memahami bahasa Inggris dalam penelitian ini yang dikaji hanya reading comphrehention (pemahaman membaca) karena terkait pemahaman artikel. Kemampuan membaca tersebut kemudian diterapkan pada beberapa pertanyaan penelitian yaitu:

1. Keseringan informan melakukan pencarian informasi dalam bahasa Inggris.

2. Sumber informasi berbahasa Inggris apa yang digunakan.

3. Pemahaman isi bacaan.

4. Hal-hal yang dilakukan untuk menguasai bahasa Inggris terkait dengan pencarian informasi melalui internet.

5. Prosentase artikel berbahasa Inggris yang digunakan dalam penulisan karya ilmiah.

6. Kesulitan yang dihadapi ketika melakukan pencarian informasi dalam bahasa Inggris.

7. Hambatan yang dialami dalam pencarian informasi berbahasa Inggris

8. Cara mengatasi kesulitan-kesulitan memahami artikel-artikel yang berbahasa Inggris tersebut.

Dari hasil wawancara dengan informan diperoleh hasil sebagai berikut: 
1. Pencarian informasi dalam bahasa Inggris

Berdasarkan pertanyaan, "Seberapa sering Anda melakukan pencarian informasi dalam bahasa Inggris?" diperoleh jawaban bahwa penggunan bahasa Inggris dalam mencari informasi hanya empat orang informan yang sering menggunakan bahasa Inggris, yang tiga orang kadang-kadang, satu orang jang dan satu orang tidak pernah menggunakan. Dengan demikian hampir separo informan sering menggunakan artikel yang berbahasa inggris, dan yang sebagian hanya kadang-kadang, dan hanya satu orang yang mengatakan tdak pernah. Berdasarkan hasil triangulasi diketahui bahwa dosen memang ada yang mewajibkan menggunakan rujukan dari artike-artikel yang ada dalam jurnal intenasional, dan dosen yang lain tidak mensyaratkannya. Oleh karena itu dapat dipahami jika ada informan yang tidak pernah menggunakan artikel berbahasa Inggris.

2. Sumber informasi berbahasa Inggris

Tentang sumber informasi berbahasa Inggris apa yang digunakan didapatkan jawaban dari informan bahwa sebagian besar mereka menjawab mendapatkan sumber informasi dari e-Journal, ada yang didapat langsung dari google scholar, yang kemungkinan juga dapat berbahasa Inggris; dan hanya satu orang yang menggunakan sumber informasi dari blog dosen, yang kemungkinan dapat berbahasa Indonesia atau bisa juga berbahasa Inggris. Hal ini dapat dimengerti karena dari hasil triangulasi beberapa dosen mewajibkan menggunakan jurnal internasional, meskipun ada yang tidak mewajibkannya. Di samping itu, sumber informasi tentang Ilmu Perpustakaan dan informasi yang berasal dari buku dapat dikatakan masih sedikit. Oleh karena itu hampir semua informan menggunakan sumber yang berbahasa Inggris dari internet, baik dari jurnal internasional, maupun dari Google ataupun Google scholar.

3. Pemahaman isi bacaan

Untuk mendapatkan jawaban tentang pemahaman isi bacaan, diberikan pertanyaan : “ Apakah anda memahami isi bacaan tersebut". Kemudian didapatkan hasil delapan orang informam memahami isi bacaan, dan satu orang memahami sedikit-sedikit dan satuorang lainnya orang yang memahami bacaan jika mencari informasi sendiri, tetapi untuk materi kuliah hanya sedikit yang dia paham, karena bahasa sulit dan susah ditemukan di kamus biasa. Dengan demikian sebagian besar informan memahami isi bacaan yang mereka dapatkan.

4. Pencarian informasi melalui internet.

Berdasarkan hasil wawancara dengan informan, hal-hal yang dilakukan informan untuk menguasai bahasa Inggris dalam menterjemahkan hasil temuan 4 orang menggunakan 
kamus bahasa Inggris untuk mencari kosakata penting, mereka tidak senang menggunakan kamus online, 3 orang menggunakan kamus online, 2 orang memperkaya diri dengan mendengarkan musik dan melihat film, dan 1 orang dengan bertanya pada teman. Dengan demikian sebagian besar informan (7 orang) menggunakan kamus baik online maupun kamus cetak, yang lainnya dengan cara mereka masing sesuai selera anak muda. Di samping itu ada yang dengan memperbanyak belajar kosak kata bahasa Inggris dan membiasakan membaca teks bahasa Inggris terkait informasi yang mereka butuhkan.. Berdasarkan pengamatan peneliti, memang ada beberapa mahasiswa yang pinjam kamus tercetak di perpustakaan maupun di progrm studi. Hal ini dapat dimaklumi karena dengan kamus online terkadang terjemahannya masih belum jelas.

5. Artikel berbahasa Inggris yang digunakan dalam penulisan karya ilmiah

Dalam menjawab pertanyaan seberapa sering informan menggunakan artikel berbahasa Inggris hanya 4 informan yang sering menggunakan bahasa Inggris, yang 4 orang kadang-kadang, 2 orang jarang dan 1 orang tidak pernah menggunakan. Empat orang informan tersebut antara $50 \%$ lebih artikel yang digunakan berbahasa Inggris, dan 4 orang kurang dari $50 \%$ yang menggunakan bahasa Inggris, 1 orang sekitar $20 \%$ dan 1 orang lainnya tidak pernah. Hal ini terkait dengan kemampuan mereka dan dalam penguasaan bahasa Inggris, ada yang mendapat nilai baik dalam mata kuliah Integrated skills dengan nilai $\mathrm{B}$ dan $\mathrm{A}$, tetapi ada pula yang mendapat $\mathrm{D}$, dan setelah diperbaiki baru mendapat $\mathrm{C}$.

6. Kesulitan yang dihadapi ketika melakukan pencarian informasi dalam bahasa Inggris

Informan dalam menjawab pertanyaan Bagaimana mengatasi kesulitan-kesulitan memahami artikel-artikel berbahasa Inggris tersebut, mereka menjawab bahwa Untuk mengatasi kesulitan bahasa 5 orang informan menggunakan Google translatel kamus online, 1 orang menggunakan Google translate dulu, kemudian di selaraskan dan 5 orang menggunakan kamus tercetak. Dengan demikan separo informan menggunakan Google translate dan separo sisanya menggunakan kamus tercetak. Hal ini dapat dipahami karena untuk menggunakan kamus daring, harus tersmbung dengan internet. Padahal berdasarkan pengamatan, internet di fakultas sering lambat jalannya, sinyal wifi nya kecil. Oleh karena itu jika mereka terdesak waktu mereka menggunakan kamus tercetak. Berdasarkan pengamatan, memang banyak mahasiwa yang pinjam kamu tercetak di perpustakaan.

7. Hambatan yang dialami dalam pencarian informasi berbahasa Inggris 
Berdasarkan pertanyaan hambatan apa saja yang dialami dalam pencarian informasi berbahasa Inggris, didapat jawaban bahwa hambatan yang dialami informan dalam mencari informasi berbahasa Inggris, 4 orang informan mempunyai hambatan dalam mengartikan bacaan, karena kurang paham artinya. Kemudian 4 orang kesulitan menentukan kata kunci, dan 2 orang yang mendapatkan hasil yang tidak sesuai dengan yang dibutuhkan. Dengan demikian semua informan mendapatkan hambatan dalam pencarian informasi, meskipun pada akhirnya mereka dapat mengatasinya . Padahal kalau dilihat mata kuliah yang ditawarkan, mereka sudah mendapat mata kuliah Literasi informasi dan Temu balik informasi. Dan dari hasil pengamatan dokumen, mereka semua sudah lulus dengan nilai baik.

8. Mengatasi kesulitan-kesulitan untuk memahami artikel-artikel yang berbahasa Inggris Dari pertanyaan kepada informan tentang cara mengatasi kesulitan mamhami artikel yang berbahasa Inggris, didapat jawaban bahwa untuk mengatasi kesulitan bahasa 5 orang informan menggunakan Google translatel kamus online, 1 orang Google translate terlebih dulu, kemudian di selaraskan,dan 4 orang menggunakan kamus tercetak. Dengan demikian bisa disimpulkan bahwa semuainforman menggunakan kamus baik kamus tercetak maupun kamus daring. Hanya satu orang yang setelah menggunakan kamus daring kemudian diselaraskan. Padahal berdasarkan pengamatan, penggunaan kamus daring, seperti Google translate memang harus diselaraskan, karena seringkali pemilihan katanya kurang tepat.

\section{Simpulan}

Berdasarkan analisis hasil penelitian mengenai Penerapan Literasi Informasi berdasarkan kemampuan berbahasa Inggris: Studi Kasus Mahasiswa Prodi S1 Ilmu Perpustakaan Fakultas Ilmu Budaya UNDIP Angkatan 2013 ini, dapat ditarik simpulan sebagai berikut:

1. Sebagian besar informan menggunakan kata kunci, dan atas jawaban pertanyaan lebih lanjut mengapa menggunakannya, mereka menjawab karena hasilnya lebih tepat, jika tajuk subjeknya tepat. Jadi sebagian besar informan memahami pentingnya terminologi informasi atau kata kunci yang dicari.

2. Tentang cara mencari informasi, diperoleh jawaban bahwa tujuh dari sepuluh informan mencari informasi melalui internet, baik melalui sosial media, browsing melalui web, dan yang tiga lainnya di samping itu juga tanya ke teman-temannya dan mencari informasi ke perpustakaan. Dengan demikian mereka semua mencari informasi melalui internet dan sebagian menggunakan buku cetak. 
3. Tentang sumber informasi yang digunakan, lebih dari separo informan telah menganeka-ragamkan sumber informasi dan juga sarana- sarana pencarian informasi.

4. Tentang penggunaan strategi Boolean, sebagian besar informan sudah menggunakan Boolean logic.

5. Cara mengevaluasi materi yang ditemu balik sebagian besar informan sudah melakukan evaluasi isi informasi yan digunakannya.

6. Tentang menyitir semua sumber didapatkan hasil semua informan sudah menganeragamkan smber informasi, baik melalui perpustakan maupun internet.

7. Dalam penggunan bahasa Inggris dalam mencari informasi dapat disimpulkan bahwa separo informan sering menggunakan bahasa inggirs, dan yang sebagian hanya kadang-kadang, dan hanya satu orang yang mengatakan tdak pernah.

8. Tentang sumber informasi berbahasa Inggris apa yang digunakan didapatkan jawaban dari informan bahwa sebagian besar mereka menjawab mendapatkan sumber informasi dari e-Journal, ada yang didapat langsung dari google scholar, yang kemungkinan juga dapat berbahasa Inggris; dan hanya satu orang yang menggunakan sumber informasi dari blog dosen, yang kemungkinan dapat berbahasa Indonesia atau bisa juga berbahasa Inggris.

9. Yang dilakukan informan untuk menguasai bahasa Inggris dalam menterjemahkan hasil temuan 4 orang menggunakan kamus bahasa Inggris untuk mencari kosakata penting, mereka tidak senang menggunakan kamus online, 3 orang menggunakan kamus online, 2 orang memperkaya diri dengan mendengarkan musik dan melihat film, dan 1 orang dengan bertanya pada teman.

10. Tentang pemahaman isi bacaan, didapatkan hasil delapan orang informam memahami isi bacaan, dan satu orang memahami sedikit-sedikit dan satuorang lainnya orang yang memahami bacaan jika mencari informasi sendiri, tetapi untuk materi kuliah hanya sedikit yang dia paham, karena bahasa sulit dan susah ditemukan di kamus biasa. Dengan demikian sebagian besar informan memahami isi bacaan yang mereka dapatkan.

11. Hal-hal yang dilakukan untuk menguasai bahasa Inggris terkait dengan pencarian informasi melalui internet. sebagian besar informan ( 7 orang) menggunakan kamus baik online maupun kamus cetak, yang lainnya dengan cara melihat film dan mendengarkan musik. 
12. Keseringan menggunakan bahasa Inggris dapat disimpulakan bahwa informan menggunakan artikel berbahasa Inggris hanya 4 informan yang sering menggunakan bahasa Inggris, yang 4 orang kadang-kadang, 2 orang jarang dan 1 orang tidak pernah menggunakan. Empat orang informan tersebut antara $50 \%$ lebih artikel yang digunakan berbahasa Inggris. Empat orang informan tersebut antara $50 \%$ lebih artikel yang digunakan berbahasa Inggris, dan 4 orang kurang dari $50 \%$ yang menggunakan bahasa Inggris, 1 orang sekitar $20 \%$ dan 1 orang lainnya tidak pernah.

13. Tentang kesulitan yang dihadapi ketika melakukan pencarian informasi dalam bahasa Inggris lima informan menggunakan Google translate dan lima lainnya menggunakan kamus tercetak.

14. Hambatan yang dialami informan dalam mencari informasi berbahasa Inggris, 4 orang informan mempunyai hambatan dalam mengartikan bacaan, karena kurang paham artinya, 4 orang kesulitan menentukan kata kunci, dan 2 orang hsil ynag didapat tidak sesuai dengan yang dibutuhkan.

15. Cara mengatasi kesulitan-kesulitan memahami artikel-artikel yang berbahasa Inggri semuainforman menggunakan kamus baik kamus tercetak maupun kamus daring. Hanya satu orang yang setelah menggunakan kamus daring kemudian diselaraskan.

Dari keseluruhan hasil penelitian maka dapat disimpulkan bahwa mahasiswa angkatan 2013 telah menggunakan bahasa Inggris untuk menjadi literat. Mereka memahami kebutuhan mereka, kemudiankebanyakan mencari informasi dari jurnal-jurnal internasional baik melalui internet dan dapat mengatasi permasalahan kekurang pahaman mereka terhadap bahasa Inggris.

\section{Daftar Pustaka}

Association of College and Research Libraries. (2000). "Information Literacy Competency". (http://www.ala.org/acrl/standards/informationliteracycompeteny)

Armstrong, D; Boden, D; Town, S.; et.al. (2015). CILIP defines Information Literacy for the UK. [http://eprints.rclis.org/7459/], diakses 10 Nov.2017.

Boekhorst, A. K. 2003. "Becoming information literate in the Netherlands". Library Review, Vol. 52.

Bruce, C. (1997). The Seven Faces of Information Literacy, Adelaide : Auslib Press, 1997.

Donaldson, Christy A. 2004. "Information Literacy and the McKinsey Model: The McKinsey Strategic Problem-Solving Model Adapted to Teach Information Literacy to Graduate Business Students". Library Philosophy and Practice Vol. 6. 
May, Yona. (2017). 4 Skills (Kemampuan) Dalam Bahasa Inggris Dan Cara Menguasainya. http://www.ilmubahasainggris.com/4-skills-penting-saat-belajar-bahasa-dalam-bahasainggris-yang-wajib-kita-ketahui/. Diakses 12 Maret 2017

Pendit, PL, 2013. Digital Native, Literasi Informasi dan Media Digital : sisi pandang kepustakawanan . Makalah disampaikan dalam Seminar dan Lokakarya Perubahan Paradigma Digital Natives Perpustakaan Universitas - Universitas Kristen Satya Wacana Salatiga 17 - 18 Januari 2013. http://repository.uksw.edu/handle/123456789/4721 .

Paterson, Susanne F, and Carolyn White Gamtso. 2016. "Information Literacy Instruction in an English Capstone Course: A Study of Student Confidence, Perception, and Practice." The Journal of Academic Librarianship 43 (2). Elsevier Inc.: 143-55. doi:10.1016/j.acalib.2016.11.005.

Pinto, Maria, Rosaura Fernandez-Pascual, and Susana Puertas. 2016. “Undergraduates' Information Literacy Competency: A Pilot Study of Assessment Tools Based on a Latent Trait Model." Library \& Information Science Research 38 (2): 180-189. doi:10.1016/j.lisr.2016.05.004.

UNESCO, 2007. Information for All Programme: "Understanding Information Literacy: A Primer". Paris: UNESCO.

Zaky. (2017). 4 Keterampilan Dasar Bahasa Inggris (Efektif untuk Pemula). http://azbahasainggris.com/keterampilan-dasar-bahasa-inggris. [ 12 Nov.2017]. 